\title{
Variation of Lithium Contents in Scalp Hair Samples of Different Male Psychiatric Patients Before and After Treatment with its Pharmaceutical Supplements
}

Kazi TG*, Baloch S, Afridi HI, Talpur FN and Sahito OM

National Centre of Excellence in Analytical Chemistry, University of Sindh, Jamshoro, Pakistan

*Corresponding author: Kazi TG, National Center of Excellence in Analytical Chemistry, University of Sindh, Jamshoro-76080-Pakistan, Pakistan, Tel: +92-222-771379; Fax: +92-222-771560; E-mail: tgkazi@yahoo.com

Received date: October 17, 2016; Accepted date: November 16, 2016; Published date: November 18, 2016

Copyright: (c) 2016 Kazi TG, et al. This is an open-access article distributed under the terms of the Creative Commons Attribution License, which permits unrestricted use, distribution, and reproduction in any medium, provided the original author and source are credited.

\begin{abstract}
The biological, medical and environmental roles of lithium (Li) have attracted considerable attention over last many decades, especially as medications for treating bipolar disorder. The aim of this follow up study was to compare the Li concentration in scalp hair samples of male psychiatric patients (schizophrenia, depression and bipolar disorder), before and after treatment with Li therapy for different time intervals (six and twelve months). For comparative purpose, the scalp hair samples were also collected from healthy male subjects of same socioeconomic and age group. The scalp hair samples were oxidized by $65 \% \mathrm{HNO}_{3}: 30 \% \mathrm{H}_{2} \mathrm{O}_{2}(2: 1)$ in microwave oven. The digested scalp hair samples were analyzed for Li by flame atomic absorption spectrometry. The resulted data indicated that the contents of $\mathrm{Li}$ in scalp hair samples of different types of psychiatric patients (schizophrenia, depression and bipolar disorder) were $46.0-55.7 \%$ lower as compared to healthy individuals ( $p<0.001)$. It was observed that the Li concentration in scalp hair were enhanced $22-27 \%$ and $40-49 \%$ psychiatric disorder patients after six and twelve month's treatment with Li supplementation, respectively. It was concluded that pathogenesis of psychiatric disorders has been associated with changes in the balance of Li concentration in human subjects.
\end{abstract}

Keywords: Lithium therapy; Scalp hair; Psychiatric patients; Atomic absorption; Spectrophotometer

\section{Introduction}

Lithium ( $\mathrm{Li}$ ) is occurring naturally in food and drinking water, which may exert positive effects on mental health. There is increasing evidence that $\mathrm{Li}$ is effective in lowering the risk of suicide [1]. Several meta-analyses have shown the antisuicidal effects of $\mathrm{Li}$ in people have depression and bipolar disorder [2-4]. It was reported that subjects with depression or bipolar disorder have been found to experience long-term cognitive impairment, even when in a euthymic state [5]. Depression itself is a common illness, occurring in about 5-10\% of the population in its unipolar variety and about $2-5 \%$ of the population in its bipolar variety [6].

Lithium, a very effective agent for the prevention of mania and depression, has also been shown to have considerable neuroprotective effects, far more in extent and human relevance than any other psychotropic agent [7-11]. It was immensely investigated about the positive effects of Li therapy for different neurodegenerative illnesses [12-14]. Ohgami et al.; Prabha et al. [6,15] have been reported that, Li in drinking water have been associated with suicide rates. The other dietary sources of $\mathrm{Li}$ are grains and vegetables, and to some extent animal-derived foods [16]. The differences in the prevalence of Li used in medical practice and levels found in natural sources is tremendous $[17,18]$. The spectroscopic methods for Li determination are carried out by flame atomic emission spectrometry, flame atomic absorption spectrometry [19-21] and inductively coupled plasma atomic emission spectrometry $[22,23]$.
The aim of this study was to evaluate the beneficial effects of pharmaceutical Li supplements on different psychiatric patients. For this purpose, the level of $\mathrm{Li}$ in scalp hair samples of different psychiatric patients before and after treatment with $\mathrm{Li}$ at different time interval (six and twelve months) was studied. For this purpose scalp hair samples of patients before and after treatment was collected and analyzed after acid digestion with flame atomic absorption spectrometry. For comparative purpose scalp hair samples of adults have same age (40-60 years) and socioeconomic group were also selected.

\section{Materials and Methods}

\section{Reagents and glassware}

Ultrapure water obtained from ELGA Lab Water system (Bucks, UK) was used throughout the work. Concentrated nitric acid (65\%) and hydrogen peroxide (30\%) were purchased from Merck (Darmstadt, Germany) and checked for possible trace metal contamination. Working standard solutions of $\mathrm{Li}$ were prepared immediately prior to analysis, by stepwise dilution of certified standard solutions $(1000 \mu \mathrm{g} / \mathrm{mL})$ obtained from Fluka Kamica (Buchs), with 0.5 $\mathrm{M} \mathrm{HNO}_{3}$. All solutions were stored in polyethylene bottles at $4^{\circ} \mathrm{C}$. To check the accuracy of methodology, certified reference material (CRM) human hair NCS DC 73347, obtained from China National Analysis Center, Shanghai, was used. All glassware and plastic materials used were previously soaked for $24 \mathrm{~h}$ in $5 \mathrm{M}$ nitric acid, washed with distilled water, and finally rinsed with ultrapure water, dried, and stored in a class 100 laminar flow hoods. 
Citation: Kazi TG, Baloch S, Afridi HI, Talpur FN, Sahito OM (2016) Variation of Lithium Contents in Scalp Hair Samples of Different Male Psychiatric Patients Before and After Treatment with its Pharmaceutical Supplements. Pharm Anal Acta 7: 520. doi: $10.4172 / 2153-2435.1000520$

Page 2 of 7

\section{Apparatus}

A Pel (Osaka, Japan) domestic microwave oven, (maximum heating power of $900 \mathrm{~W}$ ) was used for digestion of the scalp hair samples. The analysis of element was carried out by Atomic absorption spectrometer of Hitachi Ltd., Model 180-50 equipped with $10 \mathrm{~cm}$ burner head and graphite furnace GA-03 and deuterium lamp as background correction system. Hitachi Model 056 recorder was used for recording the analytical data of study analyte. The single element hollow cathode lamp was used as radiation sources, at analytical wavelength $670.8 \mathrm{~nm}$, with lamp current $10 \mathrm{~mA}$. For flame mode, Oxidant (Air) $(1.6) \mathrm{kg} / \mathrm{cm}^{2}$ and fuel (Acetylene) $0.25 \mathrm{~kg} / \mathrm{cm}^{2}$ were used.

\section{Sample collection and pretreatment}

This study was performed on 197 male subjects; age ranged 40-60 years. The scalp hair $(\mathrm{SH})$ samples were collected, from 134 psychiatric patients, which were divided into three categories; Schizophrenia $(n=43)$, Depression $(n=49)$ and bipolar disorder $(n=42)$, admitted in Sir Cowasjee Jehangir Institute of Psychiatry (CJIP) Hyderabad. For comparative purpose, scalp hair samples of healthy male subjects of same age group (mostly the attendants of patients) have no any neurodisorders as referents were collected $(n=63)$. The study protocol was approved by the local ethics committee of University of Sindh, Pakistan. The persons themselves or their attendant who gave their consent were recruited for scalp hair sample collection. Before the start of this study, each participant/attendants was informed about the aim of study in local language (Sindhi and Urdu), through a formatted questionnaire to obtain verbal and written information, including demographic and lifestyle, habits such as smoking.

The patients were diagnosed by a psychiatrist using protocol reported in diagnostic and Statistical Manual of Psychiatric Disorders (Fourth Edition). The researcher with the help of doctors conducted the interview of selected Psychiatric disorder patients. These subjects did not have diabetes, kidney failure, or other disease nor had they are treated with any drug, which can interfere with nutritional status of the elements (diuretics, antihypertensive drugs or mineral supplements, etc.). Patients who were mentally retarded and suffered from comorbid psychiatric disorders were excluded from the study. Among study groups, more than $70 \%$ patient's condition was apparently worse in terms of chronic illnesses, malnutrition and poverty. Physical examinations were performed in the Sir Cowasji Jehangir Institute of Psychiatry to measure participant's weight, height, blood pressure and biochemical data. The biochemical tests of patients (before after treatment) and referents were carried out in the pathological laboratory of Psychiatric hospital, such as body mass index, hemoglobin, hematocrit, high density lipid, low density lipid, systolic blood pressure, diastolic blood pressure, serum total cholesterol, serum HDL cholesterol, serum LDL cholesterol, red blood cells, white blood cells, platelets, lymphocyte, monocytes, are shown in Tables 1a and 1b.

\begin{tabular}{|c|c|c|c|c|}
\hline \multirow[t]{2}{*}{ Parameters } & \multirow[t]{2}{*}{ Referents } & \multicolumn{3}{|c|}{ Psychiatric patients } \\
\hline & & Schizophrenia & Depression & Bipolar disorder \\
\hline $\operatorname{BMI}\left(\mathrm{kg} / \mathrm{m}^{2}\right)$ & $24.5 \pm 2.09$ & $23.9 \pm 2.02$ & $24.1 \pm 2.16$ & $22.7 \pm 1.99$ \\
\hline $\mathrm{Hb}(13.2-17.3)(\mathrm{g} / \mathrm{dL})$ & $14.8 \pm 1.02$ & $12.7 \pm 1.11$ & $13.5 \pm 1.35$ & $13.9 \pm 1.39$ \\
\hline Hct $(39-49 \%)$ & $46.4 \pm 2.09$ & $38.9 \pm 1.66$ & $36.5 \pm 1.61$ & $39.2 \pm 2.01$ \\
\hline $\mathrm{HDL}(\mathrm{mg} / \mathrm{dL})$ & $28.9 \pm 0.72$ & $27.4 \pm 0.69$ & $25.9 \pm 0.60$ & $26.7 \pm 0.65$ \\
\hline $\mathrm{LDL}(\mathrm{mg} / \mathrm{dL})$ & $106 \pm 5.09$ & $101 \pm 4.26$ & $99.3 \pm 3.55$ & $97.6 \pm 3.38$ \\
\hline Systolic blood pressure $(\mathrm{mm} \mathrm{Hg})$ & $119 \pm 4.08$ & $132 \pm 4.03$ & $129 \pm 4.05$ & $130 \pm 3.89$ \\
\hline Diastolic blood pressure $(\mathrm{mm} \mathrm{Hg})$ & $79.2 \pm 2.06$ & $82.5 \pm 2.00$ & $87.4 \pm 0.98$ & $88.3 \pm 2.04$ \\
\hline Serum total cholesterol $(\mathrm{mg} / \mathrm{dL})$ & $165 \pm 19.6$ & $169 \pm 18.8$ & $173 \pm 16.5$ & $174 \pm 18.9$ \\
\hline Serum HDL cholesterol (mg/dL) & $38.5 \pm 7.52$ & $35.5 \pm 6.34$ & $33.9 \pm 5.31$ & $36.7 \pm 6.54$ \\
\hline Serum LDL cholesterol (mg/dL) & $95.8 \pm 10.6$ & $100 \pm 9.09$ & $102 \pm 10.1$ & $105 \pm 9.13$ \\
\hline $\mathrm{RBC}\left(\mathrm{mm}^{3}\right)$ & $3.80 \pm 0.51$ & $4.10 \pm 0.60$ & $3.92 \pm 0.54$ & $3.75 \pm 0.49$ \\
\hline WBC $\left(\mathrm{mm}^{3}\right)$ & $7.60 \pm 0.60$ & $7.83 \pm 0.75$ & $7.91 \pm 0.81$ & $7.46 \pm 0.58$ \\
\hline $\mathrm{MCH}(\mathrm{Pg})$ & $31.2 \pm 1.05$ & $30.2 \pm 1.01$ & $28.7 \pm 0.93$ & $27.9 \pm 0.90$ \\
\hline PLT $\left(10^{3} / \mu \mathrm{L}\right)$ & $259 \pm 15.9$ & $265 \pm 16.2$ & $301 \pm 20.6$ & $294 \pm 18.1$ \\
\hline LY (\%) & $35.2 \pm 10.5$ & $33.3 \pm 9.92$ & $30.9 \pm 8.21$ & $29.8 \pm 7.99$ \\
\hline MO (\%) & $5.91 \pm 1.39$ & $3.51 \pm 1.11$ & $4.23 \pm 1.23$ & $2.45 \pm 0.95$ \\
\hline
\end{tabular}

Table 1a: Clinical and biochemical characteristics of referents and psychiatric patients having different disorders before treatment. BMI: Body Mass Index; Hb: Hemoglobin; Hct: Hematocrit; HDL: High Density Lipid; LDL: Low Density Lipid; RBC: Red Blood Cells; MCH: Mean Cell Hemoglobin; PLT: Platelets; LY: Lymphocyte; MO: Monocytes. 
Citation: Kazi TG, Baloch S, Afridi HI, Talpur FN, Sahito OM (2016) Variation of Lithium Contents in Scalp Hair Samples of Different Male Psychiatric Patients Before and After Treatment with its Pharmaceutical Supplements. Pharm Anal Acta 7: 520. doi: $10.4172 / 2153-2435.1000520$

Page 3 of 7

\begin{tabular}{|c|c|c|c|c|c|c|}
\hline \multirow[t]{2}{*}{ Parameters } & \multicolumn{3}{|c|}{6 months treatment } & \multicolumn{3}{|c|}{12 months treatment } \\
\hline & Schizophrenia & Depression & Bipolar disorder & Schizophrenia & Depression & Bipolar disorder \\
\hline $\mathrm{BMI}\left(\mathrm{kg} / \mathrm{m}^{2}\right)$ & $24.0 \pm 1.72$ & $24.3 \pm 1.86$ & $22.8 \pm 1.52$ & $24.4 \pm 1.81$ & $24.8 \pm 1.98$ & $23.2 \pm 1.65$ \\
\hline $\mathrm{Hb}(13.2-17.3)(\mathrm{g} / \mathrm{dL})$ & $12.9 \pm 0.82$ & $13.8 \pm 0.97$ & $14.2 \pm 0.99$ & $13.2 \pm 0.82$ & $14.1 \pm 0.94$ & $14.3 \pm 1.01$ \\
\hline Hct (39-49\%) & $39.5 \pm 2.13$ & $37.0 \pm 2.02$ & $39.9 \pm 2.87$ & $40.0 \pm 1.79$ & $37.6 \pm 2.04$ & $40.5 \pm 2.99$ \\
\hline $\mathrm{HDL}(\mathrm{mg} / \mathrm{dL})$ & $28.0 \pm 1.93$ & $26.4 \pm 1.82$ & $27.4 \pm 1.83$ & $28.3 \pm 1.71$ & $26.8 \pm 1.54$ & $27.7 \pm 2.03$ \\
\hline $\mathrm{LDL}(\mathrm{mg} / \mathrm{dL})$ & $100.3 \pm 6.51$ & $99.1 \pm 5.82$ & $97.1 \pm 6.54$ & $99.5 \pm 5.19$ & $98.2 \pm 5.05$ & $96.5 \pm 6.48$ \\
\hline $\begin{array}{l}\text { Systolic blood pressure } \\
(\mathrm{mm} \mathrm{Hg})\end{array}$ & $128 \pm 4.02$ & $125 \pm 5.31$ & $127 \pm 4.39$ & $126 \pm 5.05$ & $123 \pm 6.19$ & $124 \pm 5.32$ \\
\hline $\begin{array}{l}\text { Diastolic blood } \\
\text { pressure }(\mathrm{mm} \mathrm{Hg})\end{array}$ & $81.4 \pm 3.95$ & $83.8 \pm 5.82$ & $84.5 \pm 5.06$ & $80.5 \pm 2.67$ & $82.5 \pm 4.03$ & $81.5 \pm 4.06$ \\
\hline $\begin{array}{l}\text { Serum total cholesterol } \\
(\mathrm{mg} / \mathrm{dL})\end{array}$ & $165 \pm 7.09$ & $168 \pm 9.21$ & $164 \pm 5.33$ & $162 \pm 4.65$ & $165 \pm 5.98$ & $162 \pm 4.03$ \\
\hline $\begin{array}{l}\text { Serum HDL cholesterol } \\
(\mathrm{mg} / \mathrm{dL})\end{array}$ & $36.2 \pm 3.98$ & $34.6 \pm 5.17$ & $37.2 \pm 2.76$ & $36.5 \pm 2.54$ & $34.9 \pm 2.33$ & $37.5 \pm 2.45$ \\
\hline $\begin{array}{l}\text { Serum LDL cholesterol } \\
(\mathrm{mg} / \mathrm{dL})\end{array}$ & $99.2 \pm 6.21$ & $100.5 \pm 6.16$ & $104.3 \pm 5.39$ & $97.9 \pm 6.17$ & $98.9 \pm 3.17$ & $102 \pm 4.05$ \\
\hline $\mathrm{RBC}\left(\mathrm{mm}^{3}\right)$ & $4.03 \pm 0.31$ & $3.86 \pm 0.21$ & $3.68 \pm 0.35$ & $3.99 \pm 0.51$ & $3.78 \pm 0.23$ & $3.54 \pm 0.30$ \\
\hline WBC $\left(\mathrm{mm}^{3}\right)$ & $7.93 \pm 0.52$ & $7.76 \pm 0.57$ & $7.51 \pm 0.39$ & $7.78 \pm 0.50$ & $7.63 \pm 0.68$ & $7.39 \pm 0.46$ \\
\hline $\mathrm{MCH}(\mathrm{Pg})$ & $30.5 \pm 1.50$ & $29.0 \pm 1.30$ & $28.3 \pm 1.08$ & $31.2 \pm 0.94$ & $29.8 \pm 1.22$ & $29.0 \pm 1.43$ \\
\hline $\operatorname{PLT}\left(10^{3} / \mu \mathrm{L}\right)$ & $269 \pm 10.5$ & $309 \pm 13.5$ & $302 \pm 13.1$ & $274 \pm 12.6$ & $312 \pm 14.2$ & $305 \pm 13.9$ \\
\hline LY (\%) & $33.9 \pm 2.34$ & $31.3 \pm 2.13$ & $30.2 \pm 1.95$ & $34.6 \pm 2.44$ & $32.1 \pm 2.44$ & $31.0 \pm 2.31$ \\
\hline $\mathrm{MO}(\%)$ & $3.55 \pm 0.32$ & $4.28 \pm 0.43$ & $2.49 \pm 0.11$ & $3.62 \pm 0.42$ & $4.37 \pm 0.51$ & $2.53 \pm 0.31$ \\
\hline
\end{tabular}

Table 1b: Clinical and biochemical characteristics of Psychiatric patients having different disorders. BMI: Body Mass Index; Hb: Hemoglobin; Hct: Hematocrit; HDL: High Density Lipid; LDL: Low Density Lipid; RBC: Red Blood Cells; MCH: Mean Cell Hemoglobin; PLT: Platelets; LY: Lymphocyte; MO: Monocytes.

All psychiatric patients were treated with pharmaceutical mineral supplements as oral multi-mineral tablets (Neurolith, Risperidone, Stelazine, Haloperidol), which contains $\mathrm{Li}$ (4.9-7.0 mg/day), for 6-12 months. The criteria for selection of referent subjects were belonging to the same age group, socio-economic status and dietary habits, not suffering from any disease and not taking any mineral supplement. They were mostly the healthy family members of the patients. Prior to the biological samples collection, they have undergone a standard routine medical examination.

\section{Sampling}

The scalp hair samples were collected from the nape of the neck using stainless steel scissors. The scalp hair samples were sealed separately in labeled polyethylene zip-lock bags and were not opened until return to the laboratory. Prior to analysis, all hair samples were cut into small pieces $(2 \mathrm{~cm})$. The washing procedure carried out was that proposed by the International Atomic Energy Agency. Thus, scalp hair samples were first washed with ultrapure water and then three times with acetone, and then finally washed with ultrapure water (three times). The samples were then dried in oven at $60^{\circ} \mathrm{C}$ after washing. Hair samples were put into separate plastic envelopes with an identification number for each participant.

\section{Microwave-assisted acid digestion method}

Duplicate samples of dried scalp hair samples $(0.5 \mathrm{~g})$ of each subject were directly taken into Teflon PTFE flasks. $2 \mathrm{~mm}$ of a freshly prepared mixture of concentrated $\mathrm{HNO}_{3}-\mathrm{H}_{2} \mathrm{O}_{2}(2: 1, \mathrm{v} / \mathrm{v})$ was added to each flask and kept for $10 \mathrm{~min}$ at room temperature and placed the flasks in covered PTFE container. Then content of flasks were heated following a one-stage digestion program at $80 \%$ of total power $(900 \mathrm{~W}), 2-4 \mathrm{~min}$ was required for complete oxidation of hair matrix. After cooling, the digestion flasks were cooled and resulting solution was evaporated to semidried mass to remove excess acid and then diluted to $5.0 \mathrm{~mL}$ in volumetric flasks with $0.1 \mathrm{~mol} / \mathrm{L}$ nitric acid. Duplicate blanks (without sample) were carried through the complete procedure. The concentrations were obtained directly from calibration graphs after correction of the absorbance signal obtained for reagent blank. The validity and accuracy of the desired procedure were checked with certified reference materials of NCS DC 73347 Human Hair as well as standard addition method at two concentration levels in scalp hair samples. 
Citation: Kazi TG, Baloch S, Afridi HI, Talpur FN, Sahito OM (2016) Variation of Lithium Contents in Scalp Hair Samples of Different Male Psychiatric Patients Before and After Treatment with its Pharmaceutical Supplements. Pharm Anal Acta 7: 520. doi: $10.4172 / 2153-2435.1000520$

Page 4 of 7

\section{Statistical analysis}

All statistical analyses were performed using the computer program Excel (Microsoft Corp., Redmond, WA, USA) and Minitab 13.2 (Minitab Inc., State College, PA, USA). The results of the scalp hair samples of referents, psychiatric patients are reported as mean values with standard deviation (SD) for Li. The distribution of the data of $\mathrm{Li}$ in each study group was checked by the Shapiro-Wilk test for normality. Nonparametric Mann-Whitney $U$ tests were applied to test for significant differences in metal concentrations between referents and patients. All relationships were significant at $95 \%$ confidence interval $(\mathrm{p}<0.05)$, unless otherwise noted.

\section{Analytical figure of merit}

The linear range of calibration curve reached from the detection limit up to $500 \mu \mathrm{g} / \mathrm{L}$ for Li. The Limit of Detection (LOD) was defined as $3 \mathrm{~s} / \mathrm{m}$, where $\mathrm{s}$ is the standard deviation corresponding to 10 blank injections and $\mathrm{m}$ is the slope of the calibration graph. The LOD and LOQ were found to be 0.38 and $1.2 \mu \mathrm{g} / \mathrm{L}$, respectively. The validity and efficiency of the microwave-assisted digestion method were checked by certified reference materials of NCS DC 73347 (human hair) as well as standard addition method in a real scalp hair sample (Table 2). The precision of the microwave-assisted acid digestion was expressed as the percent of coefficient of variation (\%CV) calculated as $<5 \%$.

\begin{tabular}{|l|l|l|l|}
\hline Certified value & \multicolumn{1}{|l|}{$\begin{array}{l}\text { Microwave-assisted } \\
\text { digested method }\end{array}$} & $\%$ recovery & $\mathbf{t}_{\text {tabulated }}$ \\
\hline \multicolumn{2}{|l|}{ NCS DC 73347 Human Hair $(\mu \mathrm{g} / \mathrm{g})$} & 99.0 & 0.519 \\
\hline $2 \pm 0.1$ & $1.98 \pm 0.07$ & \multicolumn{2}{|l|}{} \\
\hline $\begin{array}{l}\text { Validation of Li analysis by standard addition method in real samples of scalp } \\
\text { hair }\end{array}$ & $\begin{array}{l}\text { Percent recovery } \\
\text { standard of Li } \mu \mathrm{g} / \mathrm{L}\end{array}$ & $\begin{array}{l}\text { Paired t test } \\
\text { texperimental }\end{array}$ \\
\hline Scalp hair $\mu \mathrm{gg} / \mathrm{Kg}$ & \multicolumn{5}{|l|}{ Experimental values } & \multicolumn{2}{|l|}{} \\
\hline Scalp hair & $301 \pm 25.8$ & - & - \\
\hline 100 & $398 \pm 28.3$ & 99.2 & 0.265 \\
\hline 200 & $496 \pm 32.2$ & 99.0 & 0.285 \\
\hline
\end{tabular}

Table 2: Lithium concentration in certified reference materials and Validation of $\mathrm{Li}$ analysis by standard addition method in real samples of scalp hair. $t_{\text {critical }}$ at $95 \% \mathrm{CI}=2.57$ at degree of freedom $5=(\mathrm{n}-1)$. apaired $\mathrm{t}$ test between standard addition in real samples and experimental values.

\section{Results}

The mean concentrations with standard deviations for Li in scalp hair samples are shown in Table 3. The concentration of $\mathrm{Li}$ in scalp hair samples of male psychiatric patients, schizophrenia, depression and bipolar disorders, before mineral supplements were found at $95 \%$ confidence interval (CI: $117-126,142-153$ and $121-130) \mu \mathrm{g} / \mathrm{kg}$ respectively. The concentration of $\mathrm{Li}$ in male referents (CI: 264-287 $\mu \mathrm{g} / \mathrm{kg}$ ) was significantly high as compared to patients $(\mathrm{p}<0.001)$. After 6 months supplementation, $22-27 \%$ Li was enhanced in scalp hair samples of psychiatric patients. After 6 months treatment, the level of $\mathrm{Li}$ in scalp hair samples of male patients of schizophrenia, depression and bipolar disorder, were found in the range of (CI: 139-151, 169-180 and $142-152 \mu \mathrm{g} / \mathrm{kg}$ ) respectively. After 12 months treatments, $40-49 \%$ Li was enhanced in scalp hair samples of patients have schizophrenia, depression and bipolar disorders, (CI: 158-173, 191-205 and 160-172 $\mu \mathrm{g} / \mathrm{kg}$ ) respectively (Table 3 ). It was observed that sequence of $\mathrm{Li}$ in scalp hair was found in decreasing order Depression $>$ bipolar disorder $>$ schizophrenia. It was also observed that after end of the treatment (12 month) in scalp hair samples of all three types of Psychiatric patients, still $46-56.7 \%$ of $\mathrm{Li}$ was lower than healthy subjects. The resulted data indicated that the treatment by lithium supplement require long duration.

\begin{tabular}{|l|l|l|l|}
\hline $\begin{array}{l}\text { Referents/Psychiatric } \\
\text { Patients }\end{array}$ & $\begin{array}{l}\text { Before } \\
\text { treatment }\end{array}$ & $\begin{array}{l}\text { After } \\
\text { months }\end{array}$ & $\begin{array}{l}\text { After } \\
\text { months }\end{array}$ \\
\hline Referents & $276 \pm 23.4$ & - & - \\
\hline Psychiatric Patients & $122 \pm 8.49$ & $146 \pm 12.8$ & $166 \pm 14.9$ \\
\hline Schizophrenia & $148 \pm 10.5$ & $175 \pm 12.5$ & $197 \pm 14.7$ \\
\hline Depression & $125 \pm 9.06$ & $147 \pm 11.9$ & $165 \pm 13.3$ \\
\hline Bipolar disorder & &
\end{tabular}

Table 3: Lithium $(\mu \mathrm{g} / \mathrm{kg})$ concentration in scalp hair samples of referents and psychiatric patients having different disorders before and after 6 and 12 months treatment.

The distribution of resulted data of $\mathrm{Li}$ in referents and patients was checked by the Shapiro-Wilk test for normality. For Li, no significant difference was observed between normal and log normal distribution. So for comparative purpose, we use data of Li in scalp hair samples of male referents and all three types of psychiatric patients at normal distributions. The unpaired Student's t-test at different degrees of freedom between male psychiatric patients and referents were calculated at different probabilities. Our calculated $t$ value exceeds that of $t_{\text {critical }}$ value at $95 \%$ confidence intervals, which indicated that the difference between means values of $\mathrm{Li}$ in referents and psychiatric patients showed significant difference $(\mathrm{p}<0.001)$.

\section{Discussion}

Lithium is ubiquitous element found in trace amounts in plants, animals and humans. The U.S. EPA estimated that the average daily Li intake ranges from 650 to $3100 \mu \mathrm{g} / \mathrm{day}$. The $\mathrm{Li}$ had already been detected in human organs and fetal tissues in the late 19th century, leading to early suggestions of possible essentiality in humans; however, medical applications of Li carbonate for the treatment of manic excitement as an essential micronutrient. Schrauzer [16] indicated that the confirmative role of $\mathrm{Li}$ for healthy neurological functions require further study.

From the industrial point of view, expect for lithium hydride, none of the other Li compounds are hazardous, nor is the metal itself. Lithium hydride is intensely corrosive and may produce burns on the skin because of the formation of hydroxides [18]. The time-weighted average was set at $0.025 \mathrm{mg} / \mathrm{m}^{3}$ for the working environment of air quality guidelines set by Occupational Safety and Health Administration. Environmental Protection Agency (EPA) recommended that the Li concentration in the drinking water supply should not exceed $700 \mu \mathrm{g} / \mathrm{L}$. However, the suitable means for the determination and of guidelines for biological index values of $\mathrm{Li}$ exposure/protection have not been established [24,25]. 
The present study provides data on Li in scalp hair obtained from the male psychiatric patients (schizophrenia, depression and bipolar disorder) before and after treatment with Li supplements for 6 and 12 months and compared the resulted data with those obtained from referents of matched age groups. The analysis of human biological samples, such as scalp hair, is generally used for the verification of deficiency of essential trace elements in the human body. The change in trace elements concentrations in biological samples might also be associated with various physiological disorders. The relationship between psychiatric disorders and trace elements has not clear yet.

In our study, the level of $\mathrm{Li}$ in scalp hair was found to be lower in the psychiatric patients as compared to referent subjects, while after supplement for different time intervals significant lower values of $\mathrm{Li}$ was observed as compared to healthy subjects $(p<0.01)$. It was reported immensely that Li has been successfully used in psychiatric treatment for more than 50 years $[26,27]$. The $\mathrm{Li}$ in the form of lithium carbonate is frequently used in the treatment of depression. The therapeutic index for $\mathrm{Li}$ is narrow (0.6-1.5 meq/L), therefore careful monitoring of optimal therapeutic value is require to avoid toxicity [28]. Therapeutic dosages of Li are effective not only in acute mania, bipolar depression, as well as for prophylaxis, suicide prevention and augmentation of affective disorders [2], but also in other conditions such as aggression, impulsiveness, attention deficit/hyperactivity and non-affective psychosis $[29,30]$ and there is evidence that $\mathrm{Li}$ inhibits deterioration in Alzheimer's disease [31].

This is also the first study to evaluate the effects of Li supplements on biochemical parameters and its levels in the scalp hair samples of psychiatric patients. In order to obtained a broader comparison from the different parts of the globe about the levels of $\mathrm{Li}$ in scalp hair samples.

\section{Effects of supplementation}

In developing countries like Pakistan, due to a high rate of poverty and illiteracy, the amounts of essential nutrients including $\mathrm{Li}$ are not sufficiently available from the diet to meet an individual's body requirements. The biochemical parameters may be improved by $\mathrm{Li}$ supplementation after six and twelve month's treatments in three types of psychiatric patients (Table 1b).

A number of Li salts are used as mood-stabilizing drugs, primarily in the treatment of bipolar disorder, where they have a role in the treatment of depression and particularly of mania, both acutely and for the long term. As a mood stabilizer, Li is probably more effective in preventing mania than depression, and reduces the risk of suicide in people with bipolar disorder [32,3]. In depression alone (unipolar disorder), $\mathrm{Li}$ can be used in addition to other antidepressants. The $\mathrm{Li}$ supplemented as lithium carbonate $\left(\mathrm{Li}_{2} \mathrm{CO}_{3}\right)$, sold under several trade names is the most common therapeutic drug, while lithium citrate $\left(\mathrm{Li}_{3} \mathrm{C}_{6} \mathrm{H}_{5} \mathrm{O}_{7}\right)$ is also used in conventional pharmacological treatments. Lithium orotate $\left(\mathrm{C}_{5} \mathrm{H}_{3} \mathrm{LiN}_{2} \mathrm{O}_{4}\right)$ has been presented as an alternative [33]. Upon ingestion, Li becomes widely distributed in the central nervous system and interacts with a number of neurotransmitters and receptors, decreasing norepinephrine (noradrenaline) release and increasing serotonin synthesis [34]. The specific biochemical mechanism of Li action in mania is unknown [35].

The biochemical parameters of psychiatric patients (before and after supplement) and referent are shown in Tables $1 \mathrm{a}$ and $1 \mathrm{~b}$. The significant decreases in hemoglobin, hematocrit, and mean platelet volume and platelet distribution width were observed in psychiatric patients as compared to referent subjects $(\mathrm{p}<0.01)$. Whilst red blood cells, white blood cells, mean cell hemoglobin, lymphocyte and monocytes were found to be higher in referent subjects than psychiatric patients. There is no significant difference in the biochemical tests, obtain from referents and psychiatric disorder patients, such as high density lipid, low density lipid, systolic blood pressure, diastolic blood pressure, serum total cholesterol, serum HDL cholesterol, serum LDL cholesterol, and platelets $(\mathrm{P}<0.05)$. After 6 months Li supplements, $0.33-3.00 \%$ improvement was observed in different biochemical parameters of psychiatric disorder patients, whilst $3-4.78 \%$ improvement was seen after 12 months treatment.

The biochemical mechanisms of action of $\mathrm{Li}$ appear to be multifactorial and inter-correlated with the functions of several enzymes, hormones and vitamins, as well as with growth and development. Treatment with $\mathrm{Li}$ salts has also been affect the thyroid function [9], where as its contribution in reducing neuroglial inflammation, increasing pre and postsynaptic protein, and reducing stress which causes structural and functional damage to the dendrites (segments of the neuron cells that receive stimulation to become active) $[7,11]$.

The cardiovascular and nervous system changes may be due to the competitive relationship between $\mathrm{Li}$ and potassium $(\mathrm{K})$ which might produce a disturbance in intracellular metabolism. The effects of $\mathrm{Li}$ on neurotransmitter, neuropeptide, and signal transduction systems have been reviewed extensively [36,37].

The physiology, pharmacology, and toxicology of Li compounds have been mentioned [38]. A provisional RDA of $\mathrm{Li}$ is $1 \mathrm{mg}$ per day for a $70 \mathrm{~kg}$ adult [16]. It is readily absorbed from the gastrointestinal tract. It accumulates more favourably in kidney, thyroid, and bone as compared to other tissues. Excretion of Li is chiefly occurring through the kidneys, whereas 80 percent of the filtered load is reabsorbed. The usual elimination half-life is $12-27 \mathrm{~h}$, but it may rise to nearly $60 \mathrm{~h}$ if renal excretion is compromised. $\mathrm{Li}$ can substitute for sodium $(\mathrm{Na}) / \mathrm{K}$ on several transport proteins. It enters cells via the amiloride-sensitive sodium channel or the $\mathrm{Na} / \mathrm{H}^{+}$exchanger. The greater part of $\mathrm{Li}$ is contained in the cells, may be taken place of $\mathrm{K}$. In general it may be competing with $\mathrm{Na}$ at certain sites for example, in renal tubular reabsorption.

Animal experiments have demonstrated that $\mathrm{Li}$ suppresses the cocaine and haloperidol,-induced super sensitivity [18]. Furthermore, Li has been found to decrease distractibility by irrelevant stimuli and produce a dose-independent improvement of selective attention that provides detailed information about the environment. It prevents behavioral alterations owing to social isolation, a mood stabilizing drug in the treatment of bipolar disorder due to neurological effects of the ion in the human body. Long-term treatment with $\mathrm{Li}$ is associated with a preservation of memory function and increased gray matter [39].

The majority of these effects may be associated with the dampening of phosphoinositide-mediated neurotransmission, which was also suggested to explain the normalizing effects of $\mathrm{Li}$ in treating both mania and depression [40].

The diet typically provides Li from $1-2.5 \mathrm{mg} / \mathrm{d}$, only 25 percent of this amount is bioavailable $[16,18]$. Since the $\mathrm{Li}$ content of foods is highly variable, some populations could have very low dietary $\mathrm{Li}$ intakes [18]. Because of the large variations of human dietary $\mathrm{Li}$ intakes, controlled experiments with psychiatric disorder patients should be conducted with $\mathrm{Li}$ at dosage levels of about $2 \mathrm{mg} /$ day by the 
Citation: Kazi TG, Baloch S, Afridi HI, Talpur FN, Sahito OM (2016) Variation of Lithium Contents in Scalp Hair Samples of Different Male Psychiatric Patients Before and After Treatment with its Pharmaceutical Supplements. Pharm Anal Acta 7: 520. doi: $10.4172 / 2153-2435.1000520$

Page 6 of 7

administration of its supplement. Treatment with Li dosage, for long periods of time, have normalizing and beneficial effect on behavior of patients, those have mild neurological disorder. In some subjects, higher dosages may be necessary; the absolute Li requirements may also be dependent on the total salt intake, the frequency and extent of physical exertion, variations of the clearance rate, and other physiological parameters.

The concentrations of Li in scalp hair samples of our understudy adult persons were lower to those reported from Luo et al. and Marlowe et al. [41,42], while higher than Schopfer and Schrauzer; Blaurock-Busch et al. [43,44] (Table 4).

\begin{tabular}{|c|c|c|c|}
\hline Author & Age group & Genders & Mean \pm SD \\
\hline \multicolumn{4}{|l|}{ Scalp hair $(\mu \mathrm{g} / \mathrm{kg})$} \\
\hline Luo et al. [41] & $20-98$ & - & 100 \\
\hline Marlowe et al. [42] & $9.43 \pm 2.81$ & Control group & $230 \pm 350$ \\
\hline \multirow[t]{2}{*}{ Schopfer et al. [43] } & $1-84$ & Male & $19 \pm 25$ \\
\hline & $1-87$ & Female & $27.5 \pm 29$ \\
\hline $\begin{array}{l}\text { Blaurock-Busch et } \\
\text { al. [44] }\end{array}$ & - & autistic children & 1.5 \\
\hline \multirow[t]{4}{*}{ Present study } & \multirow[t]{4}{*}{$40-60$} & Control group & $276 \pm 23.4$ \\
\hline & & Schizophrenia & $122 \pm 8.49$ \\
\hline & & Depression & $148 \pm 10.5$ \\
\hline & & Bipolar disorders & $125 \pm 9.06$ \\
\hline
\end{tabular}

Table 4: Comparison of Lithium contents in scalp hair $(\mu \mathrm{g} / \mathrm{g})$ of population of various parts of the world.

\section{Conclusion}

We have identified the lower levels of Li in scalp hair samples of psychiatric disorder patients. Therefore a routine biochemical assessment of its status in biological samples of patients with psychiatric disorder is an important step for the management protocol.

The decrease of $\mathrm{Li}$ in biological samples may indicate the disturbances of mineral metabolism in psychiatric disorders. After supplementation, the resulted data have shown significantly enhanced the Li level in scalp hair samples of different types of psychiatric disorders. Subject to confirmation by psychiatric study, low-dose Li supplementation could become an effective method on psychological behavior of the study subjects. In the general population, the lithiation of the communal drinking water supplies can provide a simple, safe, and economical means of reducing the incidences of psychological effect, and the use of narcotic drugs.

\section{Statement of authorship}

We'd like to thank the administration of Sir Cowasjee Jehangir Institute of Psychiatry Hyderabad, and Liaquat University of Medical and Health Sciences, Jamshoro, Pakistan. The authors would like to thank the National Centre of Excellence in Analytical Chemistry Sindh University Jamshoro for sponsoring this research project. Tasneem GK and Shahnawaz B conceived of the study, participated in its design and coordination. Hassan IA and Farah NT performed the laboratory work. Oan MS performed the biological sampling with confirmed biochemical reports and done statistical data analyses. All authors read and approved the final manuscript.

\section{Conflicts of Interest}

None declared.

\section{Acknowledgment}

The authors thank the Higher Education Commission, Pakistan to provide financial support to National Centre of Excellence in Analytical Chemistry Sindh University Jamshoro, Pakistan, sponsoring this project.

\section{References}

1. Sugawara N, Yasui FN, Ishii N, Iwata N, Terao T (2013) Lithium in tap water and suicide mortality in Japan. Int J Environ Res Publ Health 10: 6044-6048.

2. Cipriani A, Pretty H, Hawton K, Geddes JR (2005) Lithium in the prevention of suicidal behavior and all-cause mortality in patients with mood disorders: a systematic review of randomized trials. Am J Psychiatry 162: 1805-1819.

3. Baldessarini RJ, Tondo L, Davis P, Pompili M, Goodwin FK, et al. (2006) Decreased risk of suicides and attempts during longterm lithium treatment: a metaanalytic review. Bipolar Disord 8: 625-639.

4. Guzzetta F, Tondo L, Centorrino F, Baldessarini RJ (2007) Lithium treatment reduces suicide risk in recurrent major depressive disorder. J Clin Psychiatry 68: 380-383.

5. Forlenza OV, Diniz BS, Radanovic M (2011) Disease-modifying properties of long-term lithium treatment for amnestic mild cognitive impairment: Randomised controlled trial. Br J Psychiatry 198: 351-356.

6. Ohgami H, Terao T, Shiotsuki I, Ishii N, Iwata N (2009) Lithium levels in drinking water and risk of suicide. Br J Psychiatry 194: 464-465.

7. Broberg K, Concha G, Engström K (2011) Lithium in drinking water and thyroid function. Environmental Health Perspectives 119: 827-830.

8. Hampel H, Ewers M, Bürger K (2009) Lithium trial in Alzheimer's disease: A randomized, single-blind, placebo-controlled, multicenter 10week study. J Clin Psychiatry 70: 922-931.

9. Helbich M, Leitner M, Kapusta ND (2012) Geospatial examination of lithium in drinking water and suicide mortality. Int J Health Geograph 11: 1-19.

10. Nunes MA, Viel TA, Buck HS (2013) Microdose lithium treatment stabilized cognitive impairment in patients with Alzheimer's disease. Curr Alzheimer Res 10: 104-107.

11. Zarse K, Terao T, Tian J (2011) Low-dose lithium uptake promotes longevity in humans and metazoans. Eur J Nutr 50: 387-389.

12. Alvarez G, Muñoz MJR, Satrustegui J, Avila J, Bogonez E, et al. (1999) Lithium protects cultured neurons against $\beta$-amyloid-induced neurodegeneration. FEBS Lett 453: 260-264.

13. Manji HK, Moore GJ, Chen G (1999) Lithium at 50: have the neuroprotective effects of this unique cation been overlooked. Biol Psychiatry 46: 929-940.

14. Chuang DM (2004) Neuroprotective and Neurotrophic Actions of Mood Stabilizer Lithium: Can it be used to Treat Neurodegenerative Diseases. Crit Rev Neurobiol 16: 83-90.

15. Prabha S, Chandra, Girish NB (2009). Lithium in drinking water and food, and risk of suicide. Br J Psychiatry 195: 268-272.

16. Schrauzer GN (2002) Lithium: occurrence, dietary intakes, nutritional essentiality. J Am Coll Nutr 21: 14-21.

17. Jathar VS, Pendharkar PR, Pandey VK, Raut SJ, Doongaji DR, et al. (1980) Manic depressive psychosis in India and the possible role of 
Citation: Kazi TG, Baloch S, Afridi HI, Talpur FN, Sahito OM (2016) Variation of Lithium Contents in Scalp Hair Samples of Different Male Psychiatric Patients Before and After Treatment with its Pharmaceutical Supplements. Pharm Anal Acta 7: 520. doi: $10.4172 / 2153-2435.1000520$

Page 7 of 7

lithium as a natural prophylactic. II--Lithium content of diet and some biological fluids in Indian subjects. J Postgrad Med 26: 39-45.

18. Schrauzer GN, Shrestha KP (1990) Lithium in drinking water and the incidences of crimes, suicides, and arrests related to drug addictions. Biol Trace Elem Res 25: 105-113.

19. Hernandez OM, Fraga JMG, Jimenez AI, Jimenez F, Arias JJ (2005) Characterization of honey from the Canary Islands: determination of the mineral content by atomic absorption spectrophotometry. Food Chem 93: 449-458.

20. Aliasgharpour M, Hagani H (2009) Evaluation of lithium determination in three analyzers: flame emission, flame atomic absorption spectroscopy and ion selective electrode. North Am J Med Sci 1: 244-246.

21. Stecka H, Pohl P (2011) Pre-concentration of lithium prior to its determination in honey by flame optical emission spectrometry. J Braz Chem Soc 22: 677-683.

22. Vetter J (2005) Lithium content of some common edible wild-growing mushrooms. Food Chem 90: 31-37.

23. Gonzalvez A, Armenta S, De la Guardia M (2011) Geographical traceability of "Arròs de Valencia" rice grain based on mineral element composition. Food Chem 126: 1254-1260.

24. Iguchi K, Usuda K, Kono K, Dote T, Nishiura H, et al. (1999) Urinary lithium: distribution shape, reference values, and evaluation of exposure by inductively coupled plasma argon-emission spectrometry. J Anal Toxicol 23: 17-23.

25. Usuda K, Kono K, Dote T, Watanabe M, Shimizu H, et al. (2007) An overview of boron, lithium, and strontium in human health and profiles of these elements in urine of Japanese. Environ Health Prev Med 12: 231-237.

26. Cade JF (1982) Lithium salts in the treatment of psychotic excitement. Australas Psychiatry 16: 129-133.

27. Kiełczykowska M, Pasternak K, Musik I, Wronska-Tyra J, Hordyjewska A (2006) The influence of different doses of lithium administered in drinking water on lipid peroxidation and the activity of antioxidant enzymes in rats. Pol J Environ Study 15: 747-751.

28. De Montigny C, Elie R, Caillé G (1985) Rapid response to the addition of lithium in iprindole-resistant unipolar depression: a pilot study. Am J Psychiatry 142: 220-223.

29. Kingsbury SJ, Garver DL (1998) Lithium and psychosis revisited. Prog Neuropsychopharmacol Biol Psychiatry 22: 249-263.

30. Dorrego MF, Canevaro L, Kuzis G, Sabe L, Starkstein SE (2002) A randomized, double-blind, crossover study of methylphenidate and lithium in adults with attention-deficit/hyperactivity disorder: preliminary findings. J Neuropsychiatry Clin Neurosci 14: 289-295.

31. Nunes PV, Forlenza OV, Gattaz WF (2007) Lithium and risk for Alzheimer's disease in elderly patients with bipolar disorder. The Br J Psychiatry 190: 359-360.

32. Truven Health Analytics (2013) Inc. DrugPoint System (Internet) [cited 7 October 2013]. Greenwood Village, CO: Thomsen Healthcare.

33. Nieper HA (1972) The clinical applications of lithium orotate. A two years study. Agressologie: revue internationale de physio-biologie et de pharmacologie appliquees aux efets de l'agression. Europe PMC 14: 407-411.

34. Brunton L, Chabner B, Knollman B (2010) Goodman and Gilman's The Pharmacological Basis of Therapeutics (12th edn.). New York: McGrawHill Professional.

35. https://www.drugs.com/monograph/lithium-salts.html

36. Lenox RH, Watson DG (1994) Lithium and the brain: a psychopharmacological strategy to a molecular basis for manic depressive illness. Clin Chem 40: 309-314.

37. Lenox RH, Manji HK (1998) Lithium. In: Schatzberg AF, Nemeroff CB (eds.) Textbook of Psychopharmacology. American Psychiatric Press, Washington, DC, pp: 379-429.

38. Timmer RT, Sands JM (1999) Lithium intoxication. J Am Soc Nephrol 10: 666-674.

39. Mankul E, Dalwani M, Nicoletti M (2004) Brain gray matter changes after lithiumtreatment: a voxel-basedmorphometry study in healthy individuals. Biol Psychiatry 8: 202S

40. Worley PF, Heller WA, Snyder SH, Baraban JM (1988) Science (Washington) 239: 1428.

41. Luo R, Zhuo X, Ma D (2014) Determination of 33 elements in scalp hair samples from inhabitants of a mountain village of Tonglu city, China. Ecotoxicol Environ Saf 104: 215-219.

42. Marlowe M, Moon C, Errera J, Stellern J (1983) Hair mineral content as a predictor of mental retardation. Orthomol Psychiatry 12: 26-33.

43. Schopfer J, Schrauzer GN (2011) Lithium and other elements in scalp hair of residents of Tokyo Prefecture as investigational predictors of suicide risk. Biol Trace Elem Res 144: 418-425.

44. Blaurock BE, Amin OR, Dessoki HH, Rabah T (2012) Toxic metals and essential elements in hair and severity of symptoms among children with autism. Maedica 7: 38-48. 